\begin{tabular}{ccc} 
Available online at www.sinjas.journals.ekb.eg & $\overline{\text { ARU-EGYPT }}$ \\
\hline & SCREENED BY SINAI Journal of Applied Sciences
\end{tabular}

\title{
EFFECT OF SOME SOIL CONDITIONERS ON PHYSICAL AND CHEMICAL PROPERTIES OF NORTH SINAI SANDY SOILS
}

\author{
Zeinab Z.M. El-Maslamany ${ }^{*}$; Mohamed S.A. EL-Kasass and Attia A. El-Sebsy
}

Dept. Soil and Water, Fac. Environ. Agric. Sci., Arish Univ., Egypt.

\begin{tabular}{l} 
ARTICLE INFO \\
\hline Article history: \\
Received: $01 / 01 / 2020$ \\
Revised: $23 / 02 / 2020$ \\
Accepted: $07 / 04 / 2020$ \\
Available online: $01 / 05 / 2020$ \\
\hline Keywords: \\
Vinasse; \\
humic acid; \\
acrylamide polymer; \\
wheat; \\
soil conditioner \\
$\begin{array}{l}\text { (W) } \\
\text { Check for } \\
\text { updates }\end{array}$
\end{tabular}

\begin{abstract}
A pot experiment was carried out during the early winter of 2016-2017 at the Experimental Farm of Faculty of Environmental Agricultural Sciences, Arish University, to evaluate the use of some soil conditioners on physical and chemical properties of Arish sandy soil, Wheat (Triticum aestivum L., CV Sakha 94) plants were grown in pots, A surface sandy soil sample $(0-15 \mathrm{~cm})$ from the Experimental Farm of the Faculty was used in the study. Each conditioner was homogenously distributed on the soil surface and then were mixed with the upper $15 \mathrm{~cm}$ of soil surface. Grains of wheat were sown in each pot containing $20 \mathrm{Kg}$ soil. NPK fertilizers were added as recommended. Vinasse, humic acid and polyacrylamide were added at three rates $(0.5,1.0$ and $1.5(\mathrm{~W} / \mathrm{W}))$. The experimental design was complete randomized with four replicates for each treatment. Results of $\mathrm{pH}$ showed that the effect of applied both vinasse and humic acid to the soil in different rates led to slightly decrease on $\mathrm{pH}$ values gradually by increasing the rate of application. The result of acrylamide polymer shows that the effect of the application to the soil led to increase $\mathrm{pH}$ values gradually by increasing the rate of application. Results of EC in soil show that the effect of applied vinasse, humic acid and acrylamide polymer to the soil in different rates led to increase on EC values gradually by increasing the rate of application. Also, data showed an increase in available N, P and K at all application, the higher value of $\mathrm{N}$ observed on application of vinasse on rates of $\mathrm{V}_{2}$ at the initial soil sampling periods, $\mathrm{V}_{3}$ at the mid-season and harvesting soil sampling periods. The higher value of $\mathrm{P}$ observed on application of vinasse on rates $\mathrm{V}_{3}$ at the initial soil sampling periods and $\mathrm{HA}_{3}$ at the mid-season and harvesting soil sampling periods and the higher value of $\mathrm{K}$ observed with application of $\mathrm{V}_{3}$ at all experiment periods. Except vinasse treatments, the mean values of organic matter, significantly increased with increasing the rates of the application the higher value $\mathrm{HA}_{3}$. Also, data indicate that for all studied levels of vinasse significantly increase soil organic matter values comparing to control treatments, $\mathrm{HA}_{3}$ achieve the highest increasing values of $\mathrm{OM}$ while application of $\mathrm{PAM}_{3}$ treatment was the superior for increasing soil OM. All studied levels of vinasse significantly increased soil bulk density. Apparently, $\mathrm{HA}_{2}$ and $\mathrm{HA}_{3}$ achieved the highest reducing values of BD. Such decreases represent about $8.05 \%$ and $7.89 \%$ lower than control treatment for the previously mentioned two $\mathrm{HA}$ rates and $\mathrm{PAM}_{3}$ treatment was the superior to other $\mathrm{PAM}_{3}$ for reducing soil BD, such decrease was $0.13 \mathrm{Mg} \mathrm{m}^{-3}$ at the development stage of soil sampling and represent about $8.87 \%$ lower than control treatment. Results also revealed that there was a pronounced decreasing in soil $\mathrm{K}_{\mathrm{s}}$ at the Initial period of soil sampling. Soil moisture content in both field capacity and witting point were increase along most of the studied soil sampling stages. The highest N, P and K content in grains was found for addition $\mathrm{V}_{3}$. Also, the highest grains yield was found for addition (vinasse) $\mathrm{V}_{3}$ while the control treatment had the lowest values.
\end{abstract}

\footnotetext{
* Corresponding author: E-mail address: rina.sttar92@gmail.com https://doi.org/10.21608/SINJAS.2020.86388

(c) 2020 SINAI Journal of Applied Sciences. Published by Fac. Environ. Agric. Sci., Arish Univ. All rights reserved.
} 


\section{INTRODUCTION}

Sandy soils contain high proportion of sand particles, more than sixty eight percent by weight in their mechanical composition and clay contents less than eighteen percent in the first hundred centimeter of the column. Physical properties of sandy soils are dominated by their texture. Sandy soils are not very well aggregated; they have weak soil structure or they remain single grained. They have little shrinking or expansion properties due to the low clay content and the high proportion of low activity clays (Khan, 2018) When sandy soils dry, they develop very few thin cracks organized in a loose network. Sandy soils show a wide range of porosities and bulk densities (BD). In most sandy soils, bulk density is higher and consequently total porosity is lower than silty and clayey soils (Bruand et al. 2005). Physical quality of coarse-textured soils (sandy, loamy sand, and sandy loam) is often poor due to high percentage of macropores, which results in losses of water and nutrients from the root zone via leaching (Narjary and Aggarwal, 2014). Sandy soils have a wide range of limitations for agricultural production including nutrient deficiencies, low water holding capacity, susceptibility to wind erosion on sandy dunes high macroporosity, excessive drainage, low retention of irrigation water, high percolation and leaching, high evaporation, low soil organic matter content and low fertility (Hoa et al., 2010). Sandy soil in Egypt comprises most new reclaimed soils. It is generally poor in plant nutrients and the nutrients applied to it are subject to loss by irrigation water. Also, it is often considered as a soil with physical properties of no structure, poor water retention and high permeability. Moreover, it is much more sensitive to climatic fluctuation than other soil types, because of the high variance in its status is associated with the fact that it is highly prone to droughts even during the wet season (Philip et al., 2009). One of the main factors affecting plant growth in sandy soils is the types and amounts of fertilizers. However, the cost of mineral fertilizers has been significantly going up and up. As a result, it has become necessary to seek alternatives that would supply the poor soil with more economic sources of fertilizers Rodriguez (2000).

Soil amendment compounds are materials added to soil to improve its physical and fertility properties., water retention, permeability, water infiltration, drainage, aeration, structure and nutrients availability. By this, a better environment for roots in addition to the plant growth is provided (Davies et al., 2004). In many industrial and agricultural processes, some by-products are produced apart from the useful products. A few years ago, these byproducts were considered as waste and were often disposed of, causing environmental problems. Recently, it was well recognized that by-products should be considered as useful material, and methods and technologies should be developed to reuse them. In many cases, agriculture can offer a potential solution to these problems by using the material as a substitute for chemical fertilizers and, when the organic matter content is high, as a mean of improving soil texture Gemtos et al. (1999).

Vinasse improves almost factors involved in soil fertility, provides favoring conditions for nitrogen assimilation into the soil, protects nutrients against washing out in winter and maintains them as reserve nutrients as a slow release during the vegetative period. These are the most important affect, leading to increase yield and quality of crops. Concentrated vinasse 
can be regarded as industrial by-product containing valuable active substances, recyclable to plant cultivation, Debruck and Lewcki (1990). Seedling emergence, plantlet growth and nutrient content of sunflower grown in plots, in three different soil types, were not negatively affected by the application of moderate dose of pure vinasse. The application of vinasse at sowing can partially avoid losses of $\mathrm{N}$ that can take place if the vinasse is applied too far in advance of sowing, Murillo et al. (1998). Moreover, Gemtos et al. (1999) studied the vinasse rate, time of application and compaction effect on soil properties and durum wheat crop to evaluate the effect of sugar cane industry wastes on some chemical soil properties, macro and micronutrients ( $\mathrm{N}, \mathrm{P}$ and $\mathrm{K}),(\mathrm{Fe}, \mathrm{Zn}, \mathrm{Mn}$ and $\mathrm{Cu}$ ) availability to wheat plants. Moreover, Parnaudeau et al. (2007) mentioned that, both diluted and concentrated vinasse can be spread on agricultural fields or used as organic fertilizer. Concentrated vinasse led to a slight increase in the abundance of phenolic compounds, acid insoluble fraction and a slight decrease in the labile fraction of vinasse partially or totally derived from sugar beet.

Humic acid is the most important fraction of soil organic carbon, and is important factor for maintenance of soil fertility as it is the main constituent of organic manures, through which it supplies nutrients, improve soil aggregation, and stimulate microbial diversity. Humic acid extracted from different organic sources is mostly utilized in agriculture as a biofertilizer and soil conditioner (Chen et al., 2004). Humic acid had a positive effect on plant growth, grain yield and quality, and photosynthetic metabolism of durum wheat crops Sebastiano et al. (2005). Humic acid is one of the major components of HS. Tejada et al. (2006) reported that the humic acid affect the plant growth both directly and indirectly, the indirect effect of humic acid improves physical, chemical and biological condition of soil, while the direct effects are attributed to its metabolic activity in plant growth.

Polyacrylamide (PAM) appears quite promising material as an economical hydrophilic conditioner for sandy soils (De Boodt, 1972). It is in fact one of the important water-soluble products which, by cross linkage can give an insoluble polymer in the soil with good adhesive properties (Schamp and Huylebroeck, 1972). Most of the work done with PAM was mainly for improving the hydro physical properties of sandy soils and erosion control. However, little attention was paid to its effect on the nutritional status of such soils (Potros et al., 1984) and the interaction between the polymer and plant nutrients in this soil (Abd El-Hady, 1985).

This work aimed to study the effect of some conditioner treatments on chemical and physical properties on sandy soil. Also, it included their effects on wheat plant as a constructive Crop.

\section{MATERIALS AND METHODS}

A pot experiment was carried out in the Experimental Farm, Faculty of Environmental Agricultural Sciences, Arish University, Egypt, to evaluate the use of some soil conditioners (Vinasse, Humic acid and Acrylamide Polymer) on physical and chemical properties of Arish sandy soil, using wheat (Triticum aestivum L., CV Sakha 94). Concentrated vinasse is provided by Integrated Industries and Sugar co., El-Hawamdia, Egypt, Humic acid and acrylamide polymer provided by El Gomhoureya Co. For Trading. Each conditioner was homogenously distributed on the soil surface and then were mixed with the upper $15 \mathrm{~cm}$ of the soil. The experiment was assigned for wheat (Triticum aestivum L., CV Sakha 94) cultivation in pots $(30 \mathrm{~cm}$ diameter $\mathrm{x} 40 \mathrm{~cm}$ 
depth), on 26 Nov. (2016), $1 \mathrm{~g}$ grains was sown in each pot containing $20 \mathrm{Kg}$ soil which enhanced with superphosphate as recommended.

The pots experiment included the following treatments:

- $\mathrm{V}_{1}, \mathrm{~V}_{2}$ and $\mathrm{V}_{3}(10,20$ and $30 \mathrm{ml} / \mathrm{Pot})$ of Vinasse.

- $\mathrm{HA}_{1}, \mathrm{HA}_{2}$ and $\mathrm{HA}_{3}(100,200$ and $300 \mathrm{mg}$ (Pot) of Humic Acid.

- $\mathrm{PAM}_{1}, \mathrm{PAM}_{2}$ and $\mathrm{PAM}_{3}(160,320$ and $480 \mathrm{mg} / \mathrm{Pot}$ ) of Acrylamide Polymer.

The treatments were included 3 rates $(0.5,1$ and $1.5 \mathrm{~W} / \mathrm{W})$ in addition to control treatment.

All treatments were enhanced with the same quantity of urea as recommended.

Some chemical and physical characteristics of the tested soil sample are shown in Table (1), while chemical analysis of irrigation water is shown in Table (2) and chemical analysis of vinasse are shown in Table (3).

Soil samples were collected and yield data were estimated in three stage (After added conditioners on $26^{\text {th }}$ Nov. (Initial soil sampling stage, After 2 months from added conditioners on $26^{\text {th }}$ January (mid-season soil sampling period) and after harvesting on $26^{\text {th }}$ April (harvesting soil sample period) as follow:

Soil $\mathrm{pH}$ was determined in saturation soil paste according to Richards, (1954). The electrical conductivity (ECe), $\mathrm{dSm}^{-1}$ using the conductivity meter as described by Klute, (1986). Available (NPK) in the soil were determined as described by Jackson, (1973). Organic matter content was determined according to Walkley and Black procedure (Nelson and Sommers, 1982).

The Bulk density values were determined using undisturbed soil cores according to (USDA 2014) using the following formula: $\mathrm{BD}=\frac{M s}{V t}$ Where: $-\mathrm{BD}$
$=$ Bulk density $\left(\mathrm{Mgm}^{-3}\right)$, Ms $=$ The mass of soil $(\mathrm{g})$ and $\mathrm{Vt}=$ The total volume of soil $\left(\mathrm{cm}^{3}\right)$.

Hydraulic conductivity was determined using undisturbed core samples according to USDA (2004), values of hydraulic conductivity were calculated using Darcy's law. $\frac{Q}{A t}=K t \frac{H}{L}$ Where: $\mathrm{Q}=$ the volume of water passing through the soil column at time, $\mathrm{A}=$ Area of the column. $\mathrm{H} / \mathrm{L}=$ the hydraulic gradient. and $\mathrm{Kt}=$ The hydraulic conductivity at $\mathrm{t}^{\circ} \mathrm{c}$.

Soil moisture constants (field capacity "FC" and wilting point "WP") the moisture content of the samples at each soil water suction was measured gravimetrically. The determination of soil moisture equilibrium values was carried out according to the method described by (USDA 2014), for this purpose, an air-dried undisturbed soil core was water saturated by placing it in retainer rubber rings on the porous, saturated ceramic plate kept in a tray full of water. The saturated core samples were kept in the pressure plates, and the desired pressure was applied by the air compressor until the equilibrium between the soil water suction and the water content was reached. The soil moisture retention values were determined using the pressure cooker under $0.06,0.10,0.33$ and 1.0 atmospheres, and the pressure membrane for pressures of 3.0, 5.0, 10.0 and 15 atmospheres by (Soil moisture Equipment Corp). The soil moisture content was expressed on dry weight basis (W) and volume basis $(\theta)$ using the following equations:

$\theta=\mathrm{W} \times \rho \mathrm{b} / \rho \mathrm{w}$ Where: $\rho \mathrm{b}$ is the bulk soil density and $\rho w$ is the water density.

The experimental design was complete randomized with four replicates for each treatment, the data were statistically analyzed using Co Stat computer program. The least significant difference (LSD) at 0.01 level was used for comparing the differences between means. 
Table 1. Some physical and chemical characteristics of the tested soil sample

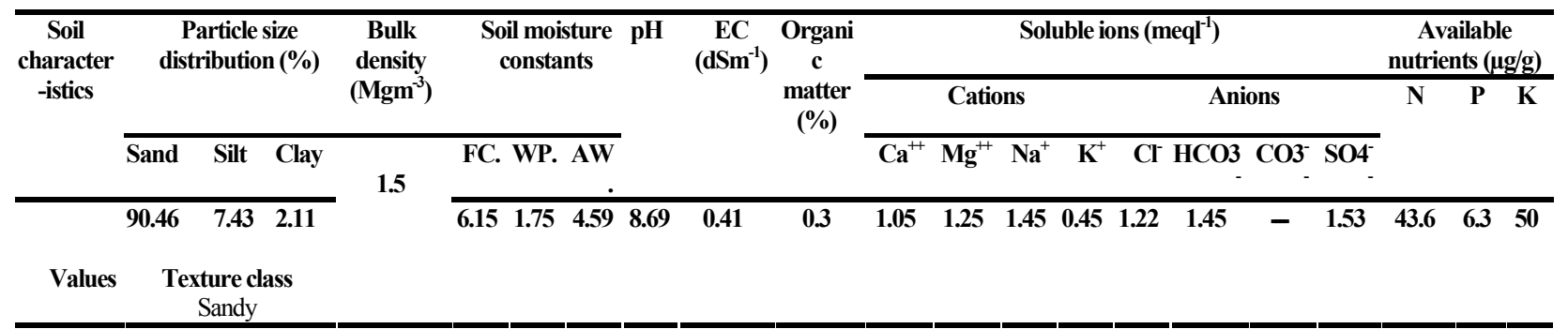

Table 2. Chemical analysis of irrigation water

\begin{tabular}{|c|c|c|c|c|c|c|c|c|c|c|}
\hline \multirow{3}{*}{$\mathbf{p H}$} & \multicolumn{2}{|c|}{ EC } & \multicolumn{8}{|c|}{ Soluble ions (meql $\left.{ }^{-1}\right)$} \\
\hline & \multirow{2}{*}{$\mathrm{dSm}^{-1}$} & \multirow{2}{*}{$\begin{array}{c}\text { T.D.S, } \\
\text { ppm }\end{array}$} & \multicolumn{4}{|c|}{ Cations } & \multicolumn{4}{|c|}{ Anions } \\
\hline & & & $\mathbf{C a}^{++}$ & $\mathbf{M g}^{++}$ & $\mathrm{Na}^{+}$ & $\mathbf{K}^{+}$ & $\mathrm{Cl}^{-}$ & $\mathrm{HCO3}^{-}$ & $\mathrm{CO3}^{--}$ & $\mathrm{SO}^{--}$ \\
\hline 8.03 & 7.93 & 5075 & 17.56 & 18.2 & 35.89 & 2.7 & 48.3 & 7.25 & - & 18.75 \\
\hline
\end{tabular}

Table 3. Chemical analysis of vinasse used in the experiment

\begin{tabular}{|c|c|c|c|c|c|c|}
\hline \multirow[b]{2}{*}{$\mathbf{p H}$} & \multirow{2}{*}{$\begin{array}{c}\text { Density } \\
\text { Kgl }^{-1}\end{array}$} & \multirow{2}{*}{$\begin{array}{c}\mathrm{EC} \\
\mathrm{dSm}^{-1}\end{array}$} & \multirow{2}{*}{$\begin{array}{l}\text { O.M } \\
\left(g^{-1}\right)\end{array}$} & \multicolumn{3}{|c|}{ Available macronutrient } \\
\hline & & & & $\mathbf{N}\left(\mathrm{gkg}^{-1}\right)$ & $P(\%)$ & $\overline{K(\%)}$ \\
\hline 4.20 & 1.29 & 8.27 & 535 & 25 & 0.09 & 7.06 \\
\hline
\end{tabular}

Source: Integrated industries and sugar Co., El-Hawamdia, Egypt.

\section{RESULTS AND DISCUSSION}

\section{Effect of Soil Conditioners on Soil Properties}

\section{Physical properties of the soil:}

\section{Soil Bulk density (BD)}

Results present in Table (4) show the effect of vinasse, humic acid and polyacrylamide during different soil sampling periods on the soil bulk density. Results presented indicate that all studied levels of vinasse significantly increase soil bulk density values compared to control treatments. The highest value was 1.70 $\mathrm{Mgm}^{-3} \mathrm{~W}$ recorded during midseason soil sampling period with $\left(\mathrm{V}_{3}\right)$ application rate which represent about $12.75 \%$ compared to control treatment. These results concomitant with Tejada and Gonzalez (2005) who reported that the soil BD was increased under the high rates of vinasse application. As regard to Humic acid treatments, values give in Table (4) clear that, all levels of (HA) application during all soil sampling periods generally resulted in significant $(P$ $\leq 0.01$ ) decreases of soil BD. Apparently, $\mathrm{HA}_{2}$ and $\mathrm{HA}_{3}$ achieved the highest reducing values of $\mathrm{BD}$, such decreases represent about $8.05 \%$ and $7.89 \%$ lower to control treatments for the previously mentioned two HA rates, respectively. Almarshadi and Ismail (2014) reported that soil amended with HA are significantly decreased soil bulk density in comparison to control treatment. With respect to polyacrylamide treatments and their influences on soil BD results in Table (4) also illustrated that, for different studied soil sampling stages, the $\mathrm{PAM}_{3}$ treatment 
Table 4. Effect of soil conditioners on soil bulk density (BD).

\begin{tabular}{|c|c|c|c|c|}
\hline \multirow[t]{3}{*}{ Treatments } & \multirow{3}{*}{$\begin{array}{l}\text { Application } \\
\text { rate }\end{array}$} & \multicolumn{3}{|c|}{ Soil sample period } \\
\hline & & Initial & Mid-season & Harvesting \\
\hline & & \multicolumn{3}{|c|}{ soil bulk density (BD) $\left(\mathrm{Mgm}^{-3}\right)$} \\
\hline \multicolumn{2}{|c|}{ Control } & $1.48 \mathrm{c}$ & $1.49 \mathrm{~d}$ & $1.52 \mathrm{c}$ \\
\hline \multirow[t]{3}{*}{ Vinasse } & V1 & $1.56 \mathrm{~b}$ & $1.54 \mathrm{c}$ & $1.61 \mathrm{~b}$ \\
\hline & $\mathbf{V} 2$ & $1.62 \mathrm{a}$ & $1.64 \mathrm{~b}$ & $1.63 \mathrm{~b}$ \\
\hline & V3 & $1.66 \mathrm{a}$ & $1.68 \mathrm{a}$ & $1.70 \mathrm{a}$ \\
\hline \multirow[t]{3}{*}{ Humic acid } & HA1 & $1.44 \mathrm{~d}$ & $1.43 \mathrm{ef}$ & $1.44 \mathrm{de}$ \\
\hline & HA2 & $1.41 \mathrm{de}$ & $1.39 \mathrm{gh}$ & $1.40 \mathrm{f}$ \\
\hline & HA3 & $1.37 \mathrm{fg}$ & $1.37 \mathrm{~h}$ & $1.40 \mathrm{f}$ \\
\hline \multirow[t]{3}{*}{ Acrylamide } & PAM1 & $1.41 \mathrm{def}$ & $1.44 \mathrm{e}$ & $1.45 \mathrm{~d}$ \\
\hline & PAM2 & $1.38 \mathrm{efg}$ & $1.43 \mathrm{ef}$ & $1.43 \mathrm{ef}$ \\
\hline & PAM3 & $1.35 \mathrm{~g}$ & $1.41 \mathrm{fg}$ & $1.40 \mathrm{f}$ \\
\hline LSD 0.01 & & 0.03 & 0.02 & 0.02 \\
\hline
\end{tabular}

was the superior to other $\mathrm{PAM}_{3}$ for reducing soil $\mathrm{BD}$, such decrease was 0.13 $\mathrm{Mg} \mathrm{m} \mathrm{m}^{-3}$ at the development stage of soil sampling and represent about $8.87 \%$ lower than control treatment. These results are in the same line with (Tayle and El-Hady, 1981; El-Hady et al., 2006) who conducted that the Hydrogel particles within the soil matrix absorb water and become lager in size.

Effect of soil conditioners on soil saturated hydraulic conductivity $\left(K_{s}\right)$

Application of the different rates of vinasse to the soil and its effects on $K_{s}$ is listed in Table (5). Obtained result clear that generally the three application rates of vinasse decreased soil $\mathrm{K}_{\mathrm{s}}$ under investigation. Such effects found true in all soil sampling stages. Results also revealed that there was a pronounced decreasing in soil at the initial stage of soil sampling. It was observed that the highest reducing in soil saturated hydraulic conductivity was $1.01 \mathrm{~m} \mathrm{day}^{-1}$ which represent about $27.30 \%$ lower than control treatment. These findings are in accordance with those obtained by Uyeda et al. (2013), who found that there was a reduction in the values of hydraulic conductivity of saturated soil.
Which can be due to higher values of organic matter of vinasse and an improvement of soil physical properties. With regard to humic acid treatments, data give in Table (5) clear that there were markedly decreases in soil $\mathrm{K}_{\mathrm{s}}$, comparing to control treatment at the different soil sampling periods. Such decreases were more pronounced with $\left(\mathrm{HA}_{3}\right)$ during the development period of soil sampling. Such percentage decrease was $28.77 \%$ lower than control treatment. Similar tendency was observed with other humic acid treatments with different magnitude. The pronounced decreases in hydraulic conductivity of the saturated soil under investigation may be due to the reaction of micropores, and the dominance of meso and micropores on the expose other pore sizes (El-Fayoumy and Ramadan (2002). Concerning the effect of polyacrylamide rates treatments, results in Table (5) reveal that the values of saturated hydraulic conductivity $\left(K_{s}\right)$ in all studied soil sampling stages ranged from 3.12 to $2.52 \mathrm{~m} \mathrm{day}^{-1}$. The applied treatments of (PAM) in the current study are significantly decreased soil $\left(\mathrm{K}_{\mathrm{s}}\right)$ with different magnitudes. Such effects were found true at all studied soil sampling stages, relative to control treatments. Such decreases under 
Table 5. Effect of soil conditioners on soil hydraulic conductivity $\left(K_{s}\right)$

\begin{tabular}{lcccc}
\hline Treatments & Application rate & \multicolumn{3}{c}{ Soil sample periods } \\
\cline { 3 - 5 } & & Initial & Mid-season & Harvesting \\
\cline { 3 - 5 } & & & $\mathbf{K}_{\mathbf{s}}\left(\mathbf{m} \mathbf{d a y}^{-1}\right)$ & \\
\hline \multirow{3}{*}{ Vinasse } & Control & $3.70 \mathrm{a}$ & $3.51 \mathrm{a}$ & $3.42 \mathrm{a}$ \\
& V1 & $3.23 \mathrm{~b}$ & $3.37 \mathrm{ab}$ & $3.15 \mathrm{c}$ \\
& V2 & $2.95 \mathrm{~cd}$ & $3.14 \mathrm{~cd}$ & $2.90 \mathrm{~d}$ \\
Humic acid & V3 & $2.69 \mathrm{e}$ & $2.81 \mathrm{f}$ & $2.76 \mathrm{e}$ \\
& HA1 & $3.18 \mathrm{~b}$ & $3.45 \mathrm{a}$ & $3.29 \mathrm{~b}$ \\
& HA2 & $2.99 \mathrm{~cd}$ & $2.99 \mathrm{de}$ & $2.81 \mathrm{de}$ \\
Acrylamide & HA3 & $2.85 \mathrm{de}$ & $2.50 \mathrm{~g}$ & $2.60 \mathrm{f}$ \\
& PAM1 & $3.12 \mathrm{bc}$ & $3.21 \mathrm{bc}$ & $3.24 \mathrm{~b}$ \\
& PAM2 & $2.97 \mathrm{~cd}$ & $2.86 \mathrm{ef}$ & $2.76 \mathrm{e}$ \\
& PAM3 & $2.84 \mathrm{de}$ & $2.52 \mathrm{~g}$ & $2.72 \mathrm{e}$ \\
& LSD 0.01 & 0.16 & 0.15 & 0.08 \\
\hline \hline
\end{tabular}

(PAM) were $0.58,0.31$ and $0.18 \mathrm{~m} \mathrm{day}^{-1}$ lower control treatments at initial, midseason and harvesting soil sampling stages, respectively. The corresponding values for $\mathrm{PAM}_{2}$ application rates were $0.73,0.65$ and $0.66 \mathrm{~m} \mathrm{day}^{-1}$, respectively. Similar trend was found with $\mathrm{PAM}_{3}$ at all studied soil sampling periods with different magnitudes. Such decreases in the soil $\mathrm{K}_{\mathrm{s}}$ values may be attribute to the decrease in the pore space between the soil particles and aggregates. The swelling of the PAM within the soil matrix was at the expense of some soil capillaries available for the water movement. Consequently, the volume of the waterconducting pores decrease, the permeability of the matrix and thus the $\mathrm{K}_{\mathrm{s}}$ decrease at low application rate of PAM (Bhardwaj et al., 2007; El-Hady et al., 2006).

\section{Soil moisture constants (SMC)}

The effect of different concentrations of vinasse on soil moisture constants and available water is shown in Table (6). Obtained results showed that there was an increase in soil moisture content for both field capacity and wilting point along most of the studied soil sampling stages under three levels of vinasse application treatments. Such increases were significant under $V_{3}$ than $\mathrm{V}_{1}$ and $\mathrm{V}_{2}$ treatments, during different soil sampling periods. Such increments of field capacity under $\mathrm{V}_{3}$ application rate were $3.33 \%, 2.18 \%$ and $2.04 \%$ during initial, mid-season and harvesting soil sampling periods, respectively over control treatments. Similar tendency was recorded with other levels of vinasse applications on field capacity and wilting point with different magnitude. Also, obtained result in Table (6) demonstrated that there was a significant $(\mathrm{P} \leq 0.01)$ increasing of available water under all studied treatments of vinasse and all studied sampling periods comparing to control treatment. Such increases of retained moisture with vinasse treatments could be due to the high content of vinasse organic matter which necessary for forming stable aggregates and increased soil structure stability (Tejada $\boldsymbol{e t}$ al., 2007). Concerning the effect of humic acid treatment on soil moisture content during the course of experimental period, obtained data in Table (6) showed that addition of different HA levels to the soil resulted in field capacity increasing soil water content and plant wilting point as well as soil available water. Such effects were found true during all studied soil sampling periods. 
Table 6. Effect of soil conditioner on soil moisture contents (SMC)

\begin{tabular}{|c|c|c|c|c|c|c|c|c|c|c|}
\hline \multirow[t]{3}{*}{ Treatments } & \multirow{3}{*}{$\begin{array}{c}\text { Application } \\
\text { rat }\end{array}$} & \multicolumn{9}{|c|}{ Soil sampling periods } \\
\hline & & \multicolumn{3}{|c|}{ Initial } & \multicolumn{3}{|c|}{ Mid- season } & \multicolumn{3}{|c|}{ Harvesting } \\
\hline & & $\mathbf{W p}$ & FC & $\mathbf{A W}$ & WP & FC & $\mathbf{A W}$ & $\mathbf{W P}$ & FC & $\mathbf{A W}$ \\
\hline \multirow{2}{*}{$\overline{\text { Control }}$} & & $1.06 \mathrm{e}$ & $5.10 \mathrm{f}$ & $4.04 \mathrm{f}$ & $1.11 \mathrm{f}$ & $5.00 \mathrm{~h}$ & $3.89 \mathrm{~g}$ & $1.23 \mathrm{e}$ & $5.17 \mathrm{f}$ & $3.95 \mathrm{f}$ \\
\hline & V1 & $1.17 \mathrm{de}$ & $6.96 \mathrm{e}$ & 9 e & $1.23 \mathrm{e}$ & $6.35 \mathrm{~g}$ & $5.12 \mathrm{f}$ & $1.26 \mathrm{cde}$ & $6.46 \mathrm{e}$ & $5.20 \mathrm{e}$ \\
\hline \multirow[t]{3}{*}{ Vinasse } & $\mathbf{V 2}$ & $1.31 \mathrm{~cd}$ & $7.53 \mathrm{~d}$ & $6.22 \mathrm{~d}$ & $1.29 \mathrm{cde}$ & $6.99 \mathrm{f}$ & $5.70 \mathrm{e}$ & $1.25 \mathrm{de}$ & $6.92 \mathrm{~d}$ & $5.67 \mathrm{~d}$ \\
\hline & $\mathbf{V 3}$ & $1.40 \mathrm{bc}$ & $8.35 \mathrm{c}$ & $6.94 \mathrm{c}$ & $1.26 \mathrm{de}$ & $7.18 \mathrm{ef}$ & $5.92 \mathrm{~d}$ & 1.29 bcde & $7.21 \mathrm{c}$ & $5.92 \mathrm{c}$ \\
\hline & HA1 & $1.22 \mathrm{cde}$ & $7.75 \mathrm{~d}$ & $6.53 \mathrm{~cd}$ & $1.27 \mathrm{de}$ & $7.26 \mathrm{e}$ & $5.99 \mathrm{~d}$ & $1.30 \mathrm{bcd}$ & $7.32 \mathrm{c}$ & $6.02 \mathrm{c}$ \\
\hline \multirow[t]{3}{*}{ Humic acid } & HA2 & $1.29 \mathrm{~cd}$ & $8.12 \mathrm{c}$ & $6.84 \mathrm{c}$ & $1.31 \mathrm{bcde}$ & $7.93 \mathrm{~d}$ & $6.61 \mathrm{c}$ & $1.33 \mathrm{abc}$ & $7.34 \mathrm{c}$ & $6.01 \mathrm{c}$ \\
\hline & HA3 & $1.35 \mathrm{~cd}$ & $8.94 \mathrm{~b}$ & $7.59 \mathrm{~b}$ & $1.38 \mathrm{bc}$ & $8.17 \mathrm{c}$ & $6.79 \mathrm{c}$ & $1.37 \mathrm{a}$ & $7.98 \mathrm{~b}$ & $6.61 \mathrm{~b}$ \\
\hline & PAM1 & $1.56 \mathrm{ab}$ & $8.27 \mathrm{c}$ & $6.71 \mathrm{c}$ & $1.33 \mathrm{bcd}$ & $8.00 \mathrm{~cd}$ & $6.67 \mathrm{c}$ & $1.35 \mathrm{ab}$ & $7.93 \mathrm{~b}$ & $6.59 \mathrm{~b}$ \\
\hline \multirow[t]{2}{*}{ Acrylamide } & PAM2 & $1.68 \mathrm{a}$ & $9.23 \mathrm{~b}$ & $7.55 \mathrm{~b}$ & $1.40 \mathrm{ab}$ & $8.59 \mathrm{~b}$ & $7.19 \mathrm{~b}$ & $1.37 \mathrm{a}$ & $8.02 \mathrm{~b}$ & $6.65 \mathrm{~b}$ \\
\hline & PAM3 & $1.74 \mathrm{a}$ & $10.17 \mathrm{a}$ & $8.44 \mathrm{a}$ & $1.47 \mathrm{a}$ & $9.23 \mathrm{a}$ & $7.76 \mathrm{a}$ & $1.39 \mathrm{a}$ & $8.61 \mathrm{a}$ & $7.22 \mathrm{a}$ \\
\hline \multicolumn{2}{|c|}{ LSD (0.01) } & 0.18 & 0.29 & 0.39 & 0.08 & 0.22 & 0.21 & 0.06 & 0.13 & 0.16 \\
\hline
\end{tabular}

$\mathrm{Wp}=$ Welting point, $\mathrm{FC}=$ Field capacity and $\mathrm{AW}=$ Available water.

Such increases were more pronounced with $\mathrm{HA}_{3}$ treatment. The increments for $\mathrm{HA}_{3}$ during harvesting soil sampling period were $2.18 \%, 0.14$ and $2.66 \%$ for field capacity, welting point and available water, respectively higher than control treatment, similar trends were recorded under other HA applications rates on different soil moisture parameters. Such results could be due to humic application improved soil physical properties and soil organic carbon. In this respect Mylonas and McCants (1980) and Majathoub (2004) noticed that there was a positive effect of water holding capacity of soil as a result of humic acid application.

\section{Chemical properties}

\section{Soil reaction $(\mathrm{pH})$}

Results presented in Table (7) show, the effect of different rates of vinasse, Humic acid and acrylamide polymer on some chemical properties of the tested soil at three periods of the experiment. The vinasse and humic acid application to the soil with different rates led to slightly decrease on $\mathrm{pH}$ values gradually by increasing the rate of application, on the other hand, acrylamide polymer application led to increase $\mathrm{pH}$ values gradually by increasing the rate of application. Higher $\mathrm{pH}$ value was observed with acrylamide polymer on $\mathrm{PAM}_{3}$. These results for vinasse are in agreement with those obtained by Mona (2010) who indicated that application of vinasse slightly decrease the values of $\mathrm{pH}$ in soil, El-Farghal and ElSherif (2012) stated that applying vinasse led to a slight decrease in the $\mathrm{pH}$ values by increasing the rate of application compared to the control. Also, Wafaa et al. (2016) found that $\mathrm{pH}$ values decreasing by application of vinasse. The results for Humic acid are in agreement with those obtained by Tahir et al. (2011) who found that higher dose of HA failed to brought any significant decrease in soil $\mathrm{pH}$. Application of fulvic acid (FA) and humic substances (HS) in combination with cyanobacteria led to significant superior decreases of $\mathrm{pH}$ and $\mathrm{EC}$ values in winter and summer seasons. However, an exception being obtained for $\mathrm{pH}$ during summer season Wafaa et al. (2013). All examined soil conditioning treatments provided a slight decrease in the $\mathrm{pH}$ values of the soil due to application of two rice straw (RS)-based hydrogels according to Houssni et al. (2016). 
El-Maslamany et al. | SINAI Journal of Applied Sciences 9 (1) 2020 041-056

Table 7. Effect of soil conditioners on $\mathrm{pH}$ and EC of the soil during studied different sampling periods

\begin{tabular}{|c|c|c|c|c|c|c|c|}
\hline \multirow{3}{*}{ Treatment } & \multirow{3}{*}{$\begin{array}{l}\text { Application } \\
\text { rate }\end{array}$} & \multicolumn{6}{|c|}{ Soil sampling period } \\
\hline & & \multicolumn{2}{|c|}{ Initial } & \multicolumn{2}{|c|}{ Mid- season } & \multicolumn{2}{|c|}{ Harvesting } \\
\hline & & pH & $\begin{array}{c}\mathrm{EC} \\
\mathrm{dSm}^{-1}\end{array}$ & pH & $\begin{array}{c}\mathrm{EC} \\
\mathrm{dSm}^{-1}\end{array}$ & pH & $\begin{array}{c}E C \\
\mathbf{d S m}^{-1}\end{array}$ \\
\hline \multirow[t]{2}{*}{ Control } & & $8.16 \mathrm{~b}$ & $0.56 \mathrm{f}$ & $8.19 \mathrm{c}$ & $1.79 \mathrm{~d}$ & $8.20 \mathrm{c}$ & $2.47 \mathrm{f}$ \\
\hline & V1 & $8.09 \mathrm{~cd}$ & $0.66 \mathrm{~d}$ & $8.11 \mathrm{de}$ & $1.93 \mathrm{bc}$ & $8.13 \mathrm{de}$ & $2.69 \mathrm{de}$ \\
\hline \multirow[t]{3}{*}{ Vinasse } & V2 & $8.05 \mathrm{de}$ & $0.70 \mathrm{bc}$ & 8.09 ef & $1.98 \mathrm{ab}$ & $8.07 \mathrm{f}$ & $2.71 \mathrm{de}$ \\
\hline & V3 & $8.00 \mathrm{f}$ & $0.77 \mathrm{a}$ & $8.06 \mathrm{~g}$ & $2.04 \mathrm{a}$ & $8.01 \mathrm{~g}$ & $2.83 \mathrm{c}$ \\
\hline & HA1 & $8.11 \mathrm{c}$ & $0.60 \mathrm{e}$ & $8.13 \mathrm{~d}$ & $1.87 \mathrm{c}$ & $8.14 \mathrm{~d}$ & $2.66 \mathrm{e}$ \\
\hline \multirow[t]{3}{*}{ Humic Acid } & HA2 & $8.08 \mathrm{~cd}$ & $0.66 \mathrm{~cd}$ & $8.08 \mathrm{fg}$ & $1.88 \mathrm{c}$ & 8.10 ef & $2.81 \mathrm{c}$ \\
\hline & HA3 & $8.02 \mathrm{ef}$ & $0.71 \mathrm{~b}$ & $8.05 \mathrm{~g}$ & $1.92 \mathrm{bc}$ & $7.99 \mathrm{~g}$ & $3.07 \mathrm{~b}$ \\
\hline & PAM1 & $8.20 \mathrm{~b}$ & $0.64 \mathrm{~d}$ & $8.23 \mathrm{~b}$ & $1.94 \mathrm{bc}$ & $8.26 \mathrm{~b}$ & $2.77 \mathrm{~cd}$ \\
\hline \multirow[t]{2}{*}{ Acrylamide } & PAM2 & $8.24 \mathrm{a}$ & $0.67 \mathrm{~cd}$ & $8.26 \mathrm{a}$ & $1.94 \mathrm{bc}$ & $8.29 \mathrm{ab}$ & $2.84 \mathrm{c}$ \\
\hline & PAM3 & $8.25 \mathrm{a}$ & $0.73 \mathrm{~b}$ & $8.28 \mathrm{a}$ & $1.97 \mathrm{ab}$ & $8.32 \mathrm{a}$ & $3.22 \mathrm{a}$ \\
\hline LSD 0.01 & & 0.04 & 0.04 & 0.03 & 0.07 & 0.04 & 0.08 \\
\hline
\end{tabular}

\section{Electrical conductivity (EC)}

Results in Table (7) show that, the values of EC, in soil was influenced by the cation of applied vinasse to the soil in different rates which led to increase in EC values gradually by increasing the rate of application, Also the same effect was found true with humic acid application. These results for vinasse are in agreement with those obtained by Usman and Gameh (2008) who found that vinasse addition to the soil with the highest level was effective in increasing the soil salinity. Also, Mona, A. Osman (2010) found that the values of EC in soil was increased by increasing the rate of vinasse. The results for Humic acid are in agreement with that obtained by Liu et al. (2019) who found that HA just significantly decreased the soil salinity. On the other hand, the application of gypsum in combined with cyanobacteria was the least affected treatment on soil salinity than other treatments. In this concern, the applied cyanobacteria treatments reduced EC, according to Molnar and Ordog (2005) who noted that some plant growth promoting regulators are found to be released by cyanobacteria such PGPRs represent the defense systems that encounter the salt stress leading to decrease the soil EC.

\section{Soil organic matter}

Results present in Table (8) show the effect of vinasse, humic acid and polyacrylamide during different soil sampling periods on the soil organic matter. Results indicated that all studied levels of vinasse significantly increase soil organic matter values which comparing to control treatment. The highest increasing value was recorded in 26 April period under $\left(V_{3}\right)$ application rate. These results for vinasse are in agreement with those obtained by Madejon et al. (2001) who found that the application of vinasse to the soil increased the organic matter content by 1.7 times greater than the mean value in the control. Also, results in Table (8) clear that $\mathrm{HA}_{3}$ 
Table 8. Effect of soil conditioners on soil organic matter (OM, \%)

\begin{tabular}{lcccc}
\hline \multirow{2}{*}{ Treatment } & Application rate & \multicolumn{3}{c}{ Soil sampling period } \\
\cline { 3 - 5 } & & Onitial & Mid- season & Harvesting \\
\cline { 3 - 5 } & & $0.19 \mathrm{e}$ & $0.21 \mathrm{e}$ & $0.25 \mathrm{de}$ \\
\cline { 3 - 5 } Control & V1 & $0.29 \mathrm{~d}$ & $0.32 \mathrm{c}$ & $0.35 \mathrm{c}$ \\
Vinasse & V2 & $0.34 \mathrm{c}$ & $0.35 \mathrm{bc}$ & $0.37 \mathrm{c}$ \\
& V3 & $0.39 \mathrm{ab}$ & $0.41 \mathrm{a}$ & $0.44 \mathrm{a}$ \\
Humic Acid & HA1 & $0.31 \mathrm{~cd}$ & $0.35 \mathrm{bc}$ & $0.39 \mathrm{bc}$ \\
& HA2 & $0.35 \mathrm{bc}$ & $0.37 \mathrm{~b}$ & $0.42 \mathrm{ab}$ \\
\multirow{2}{*}{ Acrylamide } & HA3 & $0.41 \mathrm{a}$ & $0.42 \mathrm{a}$ & $0.46 \mathrm{a}$ \\
& PAM1 & $0.21 \mathrm{e}$ & $0.25 \mathrm{~d}$ & $0.25 \mathrm{e}$ \\
LSD 0.01 & PAM2 & $0.22 \mathrm{e}$ & $0.24 \mathrm{de}$ & $0.28 \mathrm{de}$ \\
& PAM3 & $0.24 \mathrm{e}$ & $0.26 \mathrm{~d}$ & $0.30 \mathrm{~d}$ \\
& & 0.04 & 0.03 & 0.04 \\
\hline
\end{tabular}

achieve the highest increasing values of OM. These results are in agreement with Wafaa et al. (2013). The application of cyanobacteria inoculation combined with humate organic acids helpful to improve the soil properties of saline soils. Also, the cyanobacteria inoculation combined with gypsum increased organic matter. Carpenter et al. (2000) reported that HA is the most important fraction of soil organic matter, and is important factor for maintenance the soil through improving soil aggregation. With respect to polyacrylamide treatments, result in Table (8) also illustrated that, during different studied soil sampling periods, the $\mathrm{PAM}_{3}$ treatment was the superior compare to other PAM for increasing soil OM.

\section{Effect of soil conditioners on the $\mathbf{N}, \mathbf{P}$ and $K$ availability in the soil}

Data given in Table (9) show that, significant differences among all soil conditioners treatments which the higher value of available (P) was observed at treatment $\left(\mathrm{HA}_{3}\right)$. The highest soil content of available NPK is found for $\left(V_{3}\right)$ treatment of vinasse while $\left(\mathrm{PAM}_{1}\right)$ treatment had the lowest values at all period expect during the first period which recorded the lowest value with $\left(\mathrm{HA}_{3}\right)$ treatment. This result may be due to increasing of the content of NPK in the conditioner of vinasse. These results agree with Madejon et al. (2001). The results for Humic acid are in agreement with those obtained by Davies et al (2004) who said that HS. can chelate soil nutrients consequently improve their nutrient uptake, especially phosphorous, sulfur and nitrogen because they act as a storehouse of $\mathrm{N}, \mathrm{P}, \mathrm{S}$, and $\mathrm{Zn}$. The results for used polymer are in agreement with those obtained by Almarshadi and Ismail (2014) who found that addition of acrylamide gel increased $\mathrm{N}$ content in soil, significantly increased soil $\mathrm{P}$ content while it had in-significant effects on soil $\mathrm{K}$ content but higher than that of control. 
Table 9. Effect of soil conditioners on ( $N, P$ and $K$ )

\begin{tabular}{|c|c|c|c|c|c|c|c|c|c|c|}
\hline \multirow{4}{*}{ Treatments } & \multirow{4}{*}{$\begin{array}{l}\text { Application } \\
\text { rate }\end{array}$} & \multicolumn{9}{|c|}{ Soil sampling period } \\
\hline & & \multicolumn{9}{|c|}{$\mathrm{N}, \mathrm{P}$ and $\mathrm{K}(\mu \mathrm{g} / \mathrm{g})$} \\
\hline & & \multicolumn{3}{|c|}{ Initial } & \multicolumn{3}{|c|}{ Mid- season } & \multicolumn{3}{|c|}{ Harvesting } \\
\hline & & $\bar{N}$ & $\overline{\mathbf{P}}$ & $\bar{K}$ & $\mathbf{N}$ & $\overline{\mathbf{P}}$ & $\bar{K}$ & $\mathbf{N}$ & $\overline{\mathbf{P}}$ & $\bar{K}$ \\
\hline \multirow[t]{2}{*}{$\overline{\text { Control }}$} & & $45.65 \mathrm{~g}$ & $4.71 \mathrm{~g}$ & $52.93 \mathrm{e}$ & $42.58 \mathrm{~g}$ & $4.56 \mathrm{~g}$ & $49.5 \mathrm{~g}$ & $46.37 \mathrm{f}$ & $5.37 \mathrm{~h}$ & $53.21 \mathrm{c}$ \\
\hline & V1 & $77.32 \mathrm{~b}$ & $6.39 \mathrm{~d}$ & $75.19 \mathrm{c}$ & $60.31 \mathrm{~d}$ & $5.67 \mathrm{de}$ & $72.13 \mathrm{~cd}$ & $63.06 \mathrm{de}$ & $6.74 \mathrm{e}$ & $81.68 \mathrm{a}$ \\
\hline \multirow[t]{3}{*}{ Vinasse } & $\mathbf{V 2}$ & $111.76 \mathrm{a}$ & $7.59 \mathrm{~b}$ & 89.66 b & $69.47 \mathrm{c}$ & $6.23 \mathrm{~cd}$ & $83.87 \mathrm{~b}$ & $71.51 \mathrm{c}$ & $7.77 \mathrm{c}$ & $81.68 \mathrm{a}$ \\
\hline & $\mathbf{V 3}$ & $62.06 \mathrm{de}$ & $9.08 \mathrm{a}$ & $109.23 \mathrm{a}$ & $98.24 \mathrm{a}$ & $7.75 \mathrm{~b}$ & 94.59 a & $92.22 \mathrm{a}$ & $8.07 \mathrm{bc}$ & $81.68 \mathrm{a}$ \\
\hline & HA1 & $69.41 \mathrm{c}$ & $7.02 \mathrm{c}$ & $62.36 \mathrm{~d}$ & $52.43 \mathrm{e}$ & $6.77 \mathrm{c}$ & $58.81 \mathrm{ef}$ & $60.53 \mathrm{e}$ & $7.19 \mathrm{~d}$ & $72.67 \mathrm{~b}$ \\
\hline \multirow[t]{3}{*}{ Humic acid } & HA2 & $81.73 \mathrm{~b}$ & $7.82 \mathrm{~b}$ & $71.03 \mathrm{c}$ & $60.92 \mathrm{~d}$ & $8.74 \mathrm{a}$ & $65.26 \mathrm{de}$ & $67.53 \mathrm{~cd}$ & $8.27 \mathrm{~b}$ & $73.48 \mathrm{~b}$ \\
\hline & HA3 & $48.34 \mathrm{~g}$ & $8.98 \mathrm{a}$ & $82.62 \mathrm{~b}$ & $76.31 \mathrm{~b}$ & $9.01 \mathrm{a}$ & $77.92 \mathrm{bc}$ & $77.45 \mathrm{~b}$ & $8.91 \mathrm{a}$ & $77.85 a b$ \\
\hline & PAM1 & $54.7 \mathrm{f}$ & $5.02 \mathrm{~g}$ & $55.29 \mathrm{de}$ & $45.85 \mathrm{fg}$ & $5.07 \mathrm{fg}$ & $51.76 \mathrm{fg}$ & $46.05 \mathrm{f}$ & $5.78 \mathrm{~g}$ & $51.82 \mathrm{c}$ \\
\hline \multirow[t]{2}{*}{ Acrylamide } & PAM2 & $58.14 \mathrm{ef}$ & $5.45 \mathrm{f}$ & $61.01 \mathrm{~d}$ & $46.49 \mathrm{fg}$ & $5.37 \mathrm{ef}$ & $53.87 \mathrm{fg}$ & $49.5 \mathrm{f}$ & $6.25 \mathrm{f}$ & $55.4 \mathrm{c}$ \\
\hline & PAM3 & $77.32 \mathrm{~b}$ & $5.95 \mathrm{e}$ & $63.04 \mathrm{~d}$ & $48.86 \mathrm{ef}$ & $6.08 \mathrm{~d}$ & $56.85 \mathrm{fg}$ & $50.49 \mathrm{f}$ & $7.09 \mathrm{de}$ & $57.34 \mathrm{c}$ \\
\hline LSD (0.01) & & 5.80 & 0.43 & 7.36 & 5.06 & 0.55 & 7.63 & 5.65 & 0.35 & 5.78 \\
\hline
\end{tabular}

Effect of Soil Conditioners on the Concentration of $N, P$ and $K$ and Grain Yield of Wheat Plant

\section{Grains N, P and K content}

The study comprises the concentration of $\mathrm{N}, \mathrm{P}$ and $\mathrm{K}$ as a percentage of grains dry weight (total $\mathrm{N}, \mathrm{P}$ and $\mathrm{K} \%$ ) wheat plants.

\section{Nitrogen concentration ( $\mathbf{N}, \%)$}

Results presented in Table (10) show that, there were significant differences among treatments. The highest nitrogen content in grains was found as a result of $\mathrm{V}_{3}$ addition. Addition of $\mathrm{HA}_{1}$ had the lowest values. These results may be attributed to increasing content of NPK in vinasse conditioner. These results agree with Madejon et al. (2001) and David et al. (1994).

\section{Phosphorous concentration (P, \%)}

Results given in Table (10) show that, significant differences among soil conditioners addition treatments. The highest phosphorous content in grains is found for addition $\mathrm{V}_{3}$ while addition $\mathrm{PAM}_{1}$ had the lowest values. These results agree with Arafat and Abd-Elazim (2002).

\section{Potassium concentration (K\%)}

Results in Table (10) show that there were significant differences among addition conditioners treatments. The highest potassium content in grains is found for addition $\mathrm{V}_{3}$ while addition PAM1 had the lowest values. These results agree with Arafat and Abd-Elazim (2002).

\section{Wheat grain yield}

Results presented in Table (11) show that, there were significant differences among treatments. The highest grains yield was found for addition $V_{3}$ while the control treatment had the lowest values. These results may be attributed to the effect of high content of nutrient elements in vinasse conditioner compare to other used conditioners. These results agree with that obtained by Omar et al. (2000) and Madejon et al. (2001). 
Table 10. Effect of soil conditioners on $N, P$ and $K$ concentration in wheat grains.

\begin{tabular}{lcc}
\hline \multicolumn{1}{c}{ Treatment } & Application rate & Grain weight (g/pot) \\
\hline Control & V1 & $13.04 \mathrm{f}$ \\
Vinasse & V2 & $14.89 \mathrm{e}$ \\
& V3 & $16.64 \mathrm{c}$ \\
& HA1 & $20.73 \mathrm{a}$ \\
Humic Acid & HA2 & $15.5 \mathrm{de}$ \\
& HA3 & $17.32 \mathrm{c}$ \\
& PAM1 & $19.26 \mathrm{~b}$ \\
Acrylamide & PAM2 & $15.66 \mathrm{~d}$ \\
& PAM3 & $17.29 \mathrm{c}$ \\
LSD 0.01 & & $18.8 \mathrm{~b}$ \\
\hline
\end{tabular}

Table 11. Effect of soil conditioners on wheat grain yield.

\begin{tabular}{|c|c|c|c|c|}
\hline Treatment & Application rate & $\mathbf{N}(\%)$ & $P(\%)$ & $\mathbf{K}(\%)$ \\
\hline \multicolumn{2}{|c|}{ Control } & $1.44 \mathrm{f}$ & $0.37 \mathrm{e}$ & $0.44 \mathrm{f}$ \\
\hline \multirow{3}{*}{ Vinasse } & V1 & $1.67 b c$ & $0.45 \mathrm{c}$ & $0.6 \mathrm{~cd}$ \\
\hline & $\mathbf{V} 2$ & $1.75 \mathrm{ab}$ & $0.52 \mathrm{~b}$ & $0.71 \mathrm{~b}$ \\
\hline & V3 & $1.82 \mathrm{a}$ & $0.6 \mathrm{a}$ & $0.77 \mathrm{a}$ \\
\hline \multirow{4}{*}{ Humic Acid } & HA1 & $1.49 \mathrm{ef}$ & $0.4 \mathrm{de}$ & $0.5 \mathrm{e}$ \\
\hline & HA2 & $1.61 \mathrm{cde}$ & $0.53 \mathrm{~b}$ & $0.62 \mathrm{c}$ \\
\hline & HA3 & $1.71 \mathrm{abc}$ & $0.6 \mathrm{a}$ & $0.7 \mathrm{~b}$ \\
\hline & PAM1 & $1.52 \mathrm{def}$ & $0.37 \mathrm{e}$ & $0.46 \mathrm{f}$ \\
\hline \multirow{2}{*}{ Acrylamide } & PAM2 & $1.61 \mathrm{cde}$ & $0.44 \mathrm{~cd}$ & $0.52 \mathrm{e}$ \\
\hline & PAM3 & $1.64 \mathrm{bcd}$ & $0.55 \mathrm{~b}$ & $0.57 \mathrm{~d}$ \\
\hline LSD 0.01 & & 0.11 & 0.04 & 0.045 \\
\hline
\end{tabular}




\section{Conclusion}

Application of vinasse $\left(\mathrm{V}_{\mathrm{s}}\right)$ under Arish sandy soil caused a slightly decrease on $\mathrm{pH}$ and $\mathrm{K}_{\mathrm{s}}$ values and an increase in $\mathrm{EC}, \mathrm{OM}$, $(\mathrm{N}, \mathrm{P}$ and $\mathrm{K}), \mathrm{BD}$ and $\mathrm{SMC}$ (FC, WP and AW). Also, this application causes the highest $\mathrm{N}, \mathrm{P}$ and $\mathrm{K}$ content in grain and grains yield $(20 \mathrm{~g} / \mathrm{pot})$ compared to the control and all the experiment treatments. So, we recommend using it.

\section{REFERENCES}

Abdel-Fattah, M.K. (2012). Role of gypsum and compost in reclaiming saline-sodic soils. J. Agric. and Vet. Sci., 1: 30-38.

Abd El-Hady, B.M. (1985). Polyacrylamide for Dune Sand Stabilization and Controlled Release of Fertilizers nutrients. Ph.D. Thesis, Fac. Eng., Cairo Univ.

Almarshadi, M.H. and Ismail, S. (2014). Improving light textured soil properties by water regimes and soil amendments under dry land conditions. Life Sci. J., 11: 4 .

Arafat, S. and Y. Abd-Elazim (2002). Agronomic evaluation of fertilizing efficiency. Symposium No. 14. $17^{\text {th }}$ WCSS, 14-21 August. Thailand, 19911992. 6.

Bhardwaj, A.K.; Shainberg, I.; Goldstein, D.; Warrington, D.N. and Levy, G.J. (2007). Water retention and hydraulic conductivity of cross-linked polyacrylamides in sandy soils, Soil Sci. Soc. Ame. J., 71 (2): 406-412.

Bruand, A.; Hartmann, C. and Lesturgez, G. (2005). Physical properties of tropical sandy soils: a large range of behaviors. Session 4 Physical properties of tropical sandy soils. Management of Tropical Sandy Soils for Sustainable Agriculture "A holistic approach for sustainable development of problem soils in the tropics". $27^{\text {th }}$ November, $2^{\text {nd }}$ December 2005, FAO, KhonKaen, Thailand

Carpenter, B.L.; Kennedy, A.C. and Reganold, J.P. (2000). Organic and biodynamic management: Effects on soil biology. J. Soil Sci. Ame., 54:1651-1659.

Chen, Y.; De Nobili, M. and Aviad, T. (2004). Stimulatory effects of humic substanceson plant growth. In: F Magdoff and RR Weil (eds.). Soil organic matter in sustainable agriculture. CRC Press, London. Co. Stat, version 6.311, (data analysis software system) Copyright (c) 1998-2005, Co.Hort. Software (www. cohort. com.).

David, P.P.; Nelson, P.V. and Sanders, D.C. (1994). A humic acid improves growth of tomato seedling in solution culture. J. Plant Nutr., 17: 173-184.

Davies, L.C.; Novais, J.M. and MartinsDias, S. (2004). Detoxification of olive mill wastewater using superabsorbent polymers. Environ. Technol., 25: 89-100.

De Boodt, M. (1972). Improvement of soil structure by chemical means. In Optimizing the soil physical environment toward greater crop yield", Academic press, New York and London, 43-55.

Debruck, J. and Lewcki, W. (1990). Sugar beet vinasse as organic nutrient solution. Ernanrungsdienst. 29 (C.F Proc. 10 ${ }^{\text {th }}$ Microbiol. Conf., Cairo, Egypt, 100-109.

El-Farghal, W.M. and El-Sherif, A.A. (2012). Effect of rice straw compost and vinasse applications on some soil properties and yield of Egyptian clover. J. Soil Sci. and Agric. Eng., Mansoura Univ., 3 (11): 1057 - 1069.

El-Ayouty, Y.M.; Ghazal, F.M.; Hassan, A.Z.A. and Abd El-Aal, A.A.M. (2004). Effect of algal inoculation and different water holding capacity levels on soils under tomato cultivation condition. J. Agric. Sci. Mans. Univ., 29: 2801- 2809. 
El-Fayoumy, M.E. and Ramadan, H.M. (2002). Effect of bio-organic manure on sandy soils amelioration and peanut productivity under sprinkler irrigation system. Egypt. J. Soil Sci., 42(3): 838.

El-Hady, O.A.; Wana, S.A. and Shaaban, S.M. (2006). Hydrophilic polymers for improving the conditioning effect of manures and organic composts. II. Hydrophysical properties of sandy soil planted with tomato. Egypt. J. Soil Sci., 46: 283-297.

Gemtos, T.A.; Chouliaras, N. and Marakis, S. (1999). Vinasse rate, time of application and compaction effect on soil properties and durum wheat crop. J. Agric. Eng. Res., 73: 283-296.

Hoa, H.T.T.; Cong, P.T.; Tam, H.M.; Chen, W. and Bell, R. (2010). Sandy soils in South Central Coastal Vietnam: Their origin, constraints and Management. In: $19^{\text {th }}$ World Congress of Soil Science, Soil Solutions for a Changing World, 1-6 August 2010, Brisbane, Australia.

Houssni, E.; Omar, A.; Basta, A.H.; ElDewiny, C.Y. and Salah, A. (2016). Bio-chemical properties of sandy calcareous soil treated with rice strawbased hydrogels. J. Saudi Soc. Agric. Sci., 15: 188-194.

Jackson, M.L. (1973). Soil Chemical Analysis, Prentice Hall of India Pvt. Ltd., New Delhi, 38-56.

Khan, T.O. (2018). Sandy Soils, Management of Soil Problems, 37-65.

Klute, A. (1986). Methods of soil analysis. $2^{\text {nd }}$ Ed. Madison: Ame. Soc. Agron., 1: 635-686.

Liu, M.; Wang, C.; Wang, F. and Xie, Y. (2019). Maize (Zea mays) growth and nutrient uptake following integrated improvement of vermicompost and humic acid fertilizer on coastal saline soil. Appl. Soil Ecol., 142-147-154.
Liu, M.; Wang, C.; Wang, F. and Xie, Y. (2019). Maize (Zea mays) growth and nutrient uptake following integrated improvement of vermicompost and humic acid fertilizer on coastal saline soil. Appl. Soil Ecol., 142: 147-154.

Madejon, E.; Lopez, R.; Murillo, J.M. and Cabrera, F. (2001). Agricultural use of three (sugar-beet) vinasse composts: effect on crops and chemical properties of a Cambisol soil in the Guadalquivir river valley (SW Spain). Agric. Ecosyst. Environ., 84: 53-65.

Majathoub, M.A. (2004). Effects of biostumilants on production of wheat (Triticum aestivum L.). CanteroMartínez C. (ed.), Gabiña D. (ed.). Mediterranean rainfed agriculture: Strategies for sustainability, Zaragoza: CIHEAM, 147-150

Molnar, Z. and Ordog, V. (2005). The effect of cyanobacterial compounds on the organogenesis of pea cultured in vitro. Acta Biologica Szegediensis, 49: 37-38.

Osman, M.A. (2010). The possible use of diluted vinasse as a partial replacement with mineral fertilizer sources for wheat production and improving nutritional status in sandy soil. Nat. and Sci., 8 (11): 245-251.

Mona, K.M.; Nadia, M.H. and Nader, R.H. (2011). Beneficial effect of some organic soil-conditioning agents for improving sandy soil productivity under sprinkler irrigation system. Aust. J. Basic and Appl. Sci., 5 (12): 12-20, ISSN 1991-8178.

Murillo, J.M.; Cabrera, F.; Lopez, R. and Olmedo, P.M. (1998). Sunflower response to the application of a concentrated beet vinasse. Soil Sci. and Plant Anal., 29: 643-655.

Mylonas, V.A. and McCants, C.B. (1980). Effect of HA on growth of tobacco. Plant Soil, 54: 485- 490. 
Narjary, B. and Aggarwal, P. (2014). Evaluation of soil physical quality under amendments and hydrogel applications in a soybean-wheat cropping system. Communications in Soil Sci. and Plant Anal., 45: 1167-1180.

Nelson, D.W. and Sommers, L.E. (1982). Total carbon, organic carbon and organic matter. In: Methods of Soil Analysis (Ed. A.L. Page). Part 2. Agron. Monographs 9. ASA and SSSA, Madison. WI. 539-579.

Omar, M.N.A.; Mostafa, A.T. and Ahmed, A.S. (2000). Concentrated vinasse as a novel diazotrophs growth medium (biovinasse inoculant) and soil conditioner to improve faba bean yield under dripping irrigation system. Proc. $10^{\text {th }}$ Microbiol. Conf., Cairo, Egypt, 100-109.

Osman, M.A.; Mohamed, M.A.M.; Ali, M.H.H. and Al-Afify, A.D.G. (2010). Assessment of agriculture drainage water quality to be used for fish farm irrigation. Nat. and Sci., 8: 8.

Parnaudeau, V.; Condom, N.; Oliver, R.; Cazevieille, P. and Recous, S. (2007). Vinasse organic matter quality and mineralization potential, as influenced by raw material, fermentation and concentration processes. (C.F Sci. Direct-Bioresource Technol. Copyright $(\mathrm{C}$ 2007 Elsevier Ltd.

Philip, J.H. and McGregor, G. (2009). Global warming related effects on agriculture and human health and comfort, Nat., 121.

Piper, C.S. (1947). Soil and Plant Analysis. The University of Adelaide (Australia) 59-74.

Potros, N.P.; Lotfy, A.A.; El-Hady, A. and Azaam, R. (1984) Introductory studies on some soil conditioning for citrus nursery plantation. Egypt. J. Soil Sci., 25 (3): 263.

Richards, L.A. (1954). Diagnosis and Improvement of Saline and Alkali Soils.
USA Department of Agriculture Handbook 60. USDA Government Printing Office, Washington, DC.

Rodriguez, J.G. (2000): Effect of vinasse on sugarcane (Saccharum officinarum) productivity. Rev. Fac. Agron., 17: 318326.

Schamp, N. and Huylebroeck, J. (1972) The use of Polymers as soil conditioners Reprint from the second Asian Soil Conf. Proc., 73, Jakarta.

Sebastiano, D.; Roberto, T.; Ersilio, D. and Arturo, A. (2005). Effect of foliar application on $\mathrm{N}$ and humic acids on growth and yield of durum wheat. Agron. Sustain. Dev., 25 (2): 183- 191.

Tahir, M.M.; Khurshid, M.; Khan, M.Z.; Abbasi, M.K. and Kazmi, M.H. (2011). Lignite-derived humic acid effect on growth of wheat plants in different soils. Pedosphere, 21.

Tayel, M.Y. and El-Hady, O.A. (1981). Improving sandy soil structure by conditioning. Egypt. J. Soil Sci., 1-11.

Tejada, M. and Gonzalez, J.L. (2005). Beet vinasse applied to wheat under dryland conditions affects soil properties and yield. Eur. J. Argon., 23: 336-347.

Tejada, M.; Moreno, J.L.; Hernández, M.T. and García, C. (2007). Application of two beet vinasse forms on soil restoration: effects on soil properties in an arid environment in southern Spain. Agric., Ecosystems and Environ., 119: 289-298.

Tejada, M.; Hernández, M.T. and García, C. (2006). Application of two organic amendments on soil restoration: effects on the soil biological properties. J. Environ. Quality, 35: 1010-1017.

USDA (2004). Soil Survey Laboratory Methods Manual. Soil Survey Investigations Report No. 42, Version 4.0. R. Burt (ed.). U.S. Dept. Agric., Nat. Res. Conservation Service. Washington, DC. 
USDA (2014). Kellogg Soil Survey Laboratory Methods Manual. Soil Survey Investigations Report No. 42, Version 5.0. R. Burt and Soil Survey Staff (ed.). U.S. Dept. Agric., Nat. Res. Conservation Service. Washington, DC.

Usman, A.R.A. and Gameh, M.A. (2008). Effect of sugar industry wastes on $\mathrm{K}$ status and nutrient availability of a newly reclaimed loamy sandy soil. Archives Agron. and Soil Sci., 54 (6): 665-675.

Uyeda, A.C.; Jarbas, H.; Sergio, N.; Pedro, R.F. and Carlos, T. (2013). influence of vinasse application in hydraulic conductivity of three soils Eng. Agríc., Jaboticabal, 33 (4): 689-698.

Wafaa, M.A; Mona, A.O. and Mona, H.M. (2016). Utilization of vinasse and feldspar as alternative sources of potassium fertilizers and their effect on some soil properties and crop yield in sandy soils. J. Soil Sci. and Agric. Eng., Mansoura Univ. 7 (9): 669 - 675.

Wafaa, M.T.; Ghazal, F.M.A. Mahmoud and Yossef, G.H. (2013). Responses of wheat- rice cropping system to cyanobacteria inoculation and different soil conditioners sources under saline soil. Nat. and Sci., 11: 10.

\section{الملخص العربي \\ تأثير بعض مصلحات الأراضي علي الخواص الكيميائية والطبيعية للأز اضي الرملية بشمال سيناء

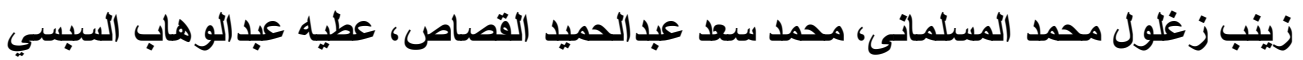 \\ قسم الأر اضي و المياه، كلية العلوم الزر اعية البيئية، جامعة العريش، مصر .}

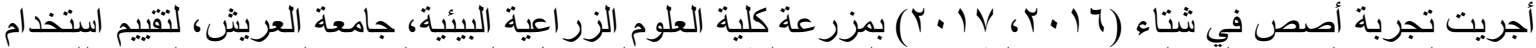

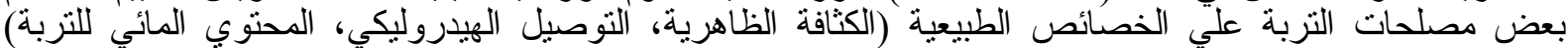

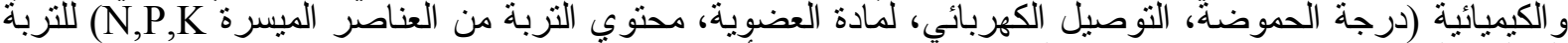

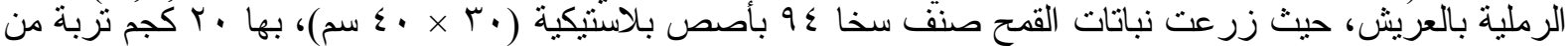

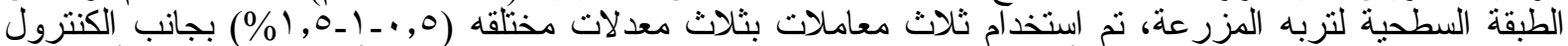

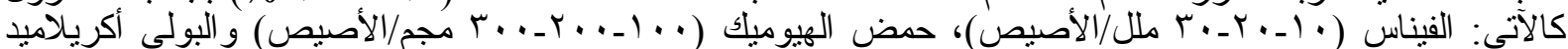

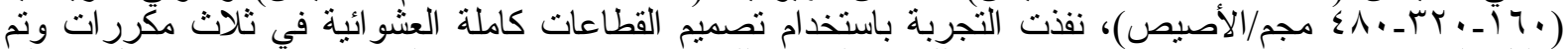

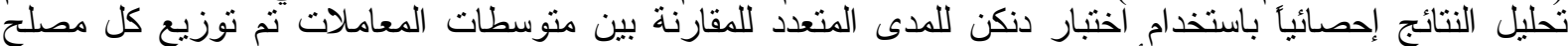

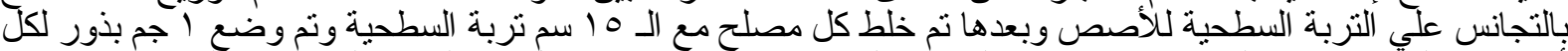

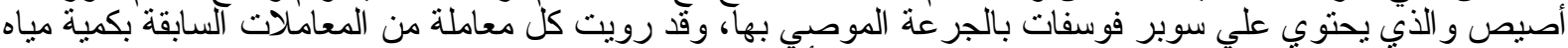

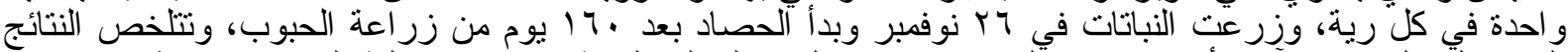

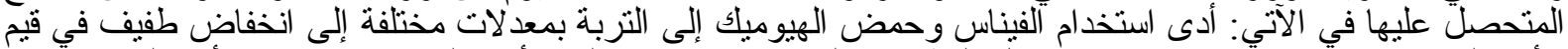

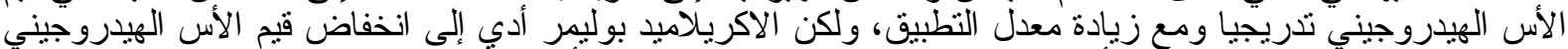

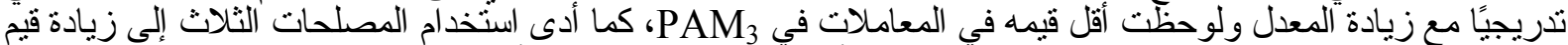

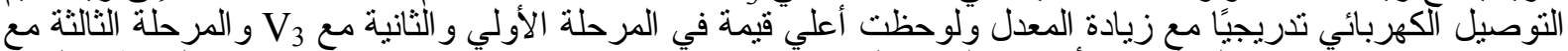

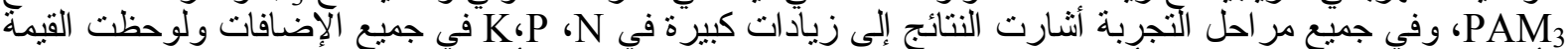

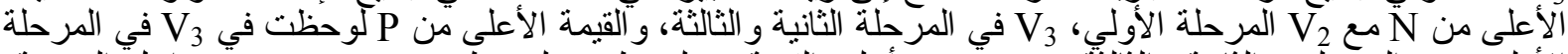

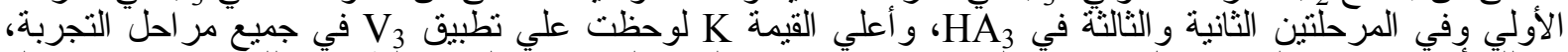

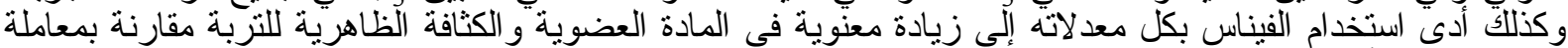

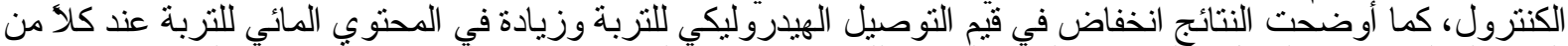

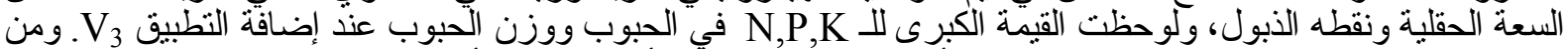

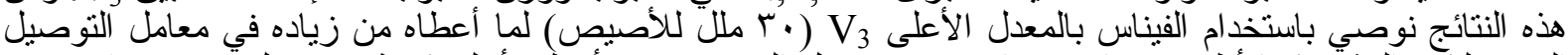

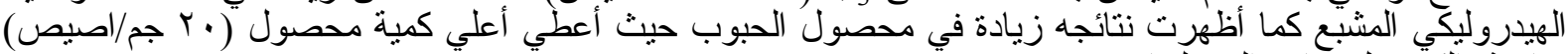
مقارنة بالكنترول وباقي المصلحات.

الكلمات الاسترشادية: فيناس، حمض الهيوميك، أكريلاميد بوليمر ، قمح، مصلحات التربة. 